\title{
The Whalers of Honfleur in the Seventeenth Century
}

\author{
J. THIERRY DU PASQUIER*
}

\section{INTRODUCTION}

The Honfleur admiralty archives have a remarkable collection of reports made by captains returning from their voyages, among which have been found the accounts of 31 whalers and one other which did not return to Honfleur. These archives also contain some lists of crews, equipment, and provisions on board. ' We have at our disposal therefore a very interesting collection of documents about 32 French whalers between 1668 and 1688. This principal source is complemented by papers from the Insurance Chamber of the City of Paris, ${ }^{2}$ minutes from the notaries of Saint-Jean de. Luz and various other documents from the Marine Archives and elsewhere.

To understand why there were whalers at Honfleur at all it is necessary to look at the context of whaling in this period. The Basques were the great whaling specialists of the seventeenth century, and they had taught their skills to the Dutch. Until 1665 the Company of the North held the whaling license. Once this privilege had expired, the number of whalers increased rapidly in the years following. A statement made in 1660 during a lawsuit against the Company of the North gives some indication of the produce of whaling: "It is known that of eighty thousand casks of whale oil produced every year, fifty thousand casks are brought back to France, of which Paris employs eight thousand, Normandy twenty thousand, Picardy eight to ten thousand, Brittany the same, Touraine a large number and the other provinces of the Kingdom the remainder". ${ }^{3}$

Thus we know that Normandy and Paris alone consumed between them more than half the oil imported into France. We can now understand why many Basque whalers went into Le Havre or Honfleur instead of returning to Saint-Jean de.Luz or Bayonne where they would have had to reship their oil to other ports. From Honfleur the oil was sent to Rouen, thence some of it down the Seine to Paris.

The first part of this paper deals with the ships, their owners and crews; the second part describes the practice of whaling.

\section{THE SHIPS AND THEIR CREWS}

\section{The Ships}

The standard French whaling vessel of this epoch was a 250-ton frigate on which the stem-post and timbers were reinforced to withstand ice pressure. ${ }^{4}$ Some ships. were smaller; for example, the Marie of 1680 and the Vierge of 1683 and 1684 only drew 100 tons, and the Saint-Etienne, fitted out at
Honfleur from 1681 to 1688 , was 160 tons. The only two vessels in our sample with a tonnage over 250 are the Esperance, wrecked in 1671 (350 tons) and the Saint-François of 1677 ( 300 tons). The Basques also used a few fluits (flee boats) either bought or taken from the Dutch, but these are not listed among the ships which returned to Honfleur ${ }^{5}$ (Table 1 ).

The ships were usually armed with 6-14 cannon, as France and Holland were often at war and the French were outnumbered almost ten to one by the Dutch whalers in Greenland waters.

\section{The Crews and their Provisions}

The muster-roll in 1684 for the 160-ton Saint-Etienne, also called Saint-Charles and Saint-Etienne, includes a list of the provisions and equipment taken on board.

The provisions consisted of: 100 quintals of bread, biscuits or cake; 25 tuns of cider; 19 quintals of dried cod; 6 hogsheads of peas; 2 hogsheads of bacon; 16 hogsheads of light wine; 60 hogsheads of water; 1 hogshead of olive oil; 1 hogshead of vinegar; 1 tierce of salt beef; and 1 tierce of brandy. This was meant to feed a crew of 39 men over a five-month period. The equipment for fishing was: 5 whaleboats with oars; 40 fishing lines (ropes to fix to the harpoons); 40 harpoons; 90 lances; and 26 knives (to cut up the whales). The ship also took the bricks, sand, and other materials needed to construct a boiler on board for melting the blubber, and coal was taken to provide heat in arctic waters. Besides the 160 casks of fresh water which acted as ballast but which were later filled with oil, the ship carried 200 dissassembled casks and the hoops necessary to put them together again.

The armament consisted of 14 cannons, 30 guns, 30 cutlasses, 24 pistols and 40 grenades.

\section{The Ship Owners}

The reports, muster-rolls, and clearance certificates do not mention the names of the owners so their identity has to be gleaned from other sources (Table 2).

Of the 32 whaling voyages studied, 22 were undertaken in ships which had left the Pays Basque and returned to Honfleur. The owners were therefore usually Basque, but the whale ships were often partly-owned by merchants from other areas. For example, the Saint-François from Ciboure, fitted out by Delalande who held a one-eighth share, was also owned by a Rouen merchant, Nicolas Mesnager, who possessed 7/24 in 
TABLE 1. Honfleur whalers. All the returns indicated put in at Honfleur. Abbreviations: $\mathrm{Gr}=\mathrm{Greenland}$; $\mathrm{Is}=\mathrm{Iceland} ; \mathrm{t}=\mathrm{tons} ; \mathrm{St}-\mathrm{J}$ de $\mathrm{L}=$ Saint-Jean de Luz; + = shipwreck

\begin{tabular}{|c|c|c|c|c|c|c|c|}
\hline No. & Name & Departure & Return & Captain & Reports & Whales & $\begin{array}{l}\text { Casks of } \\
\text { Oil }\end{array}$ \\
\hline 1 & Ste-Ursule (250 t) & & $\begin{array}{l}\text { 68.08.30, Le Havre; } \\
\text { September Honfleur }\end{array}$ & Fs Detcheverry & $\begin{array}{l}\text { Left Gr } 08.01 \text {, begin unloading at } \\
\text { Havre }\end{array}$ & & \\
\hline 2 & St-François $(180 \mathrm{t})$ & 69.04.19 Ciboure & $69: 10.03$ & P. Daccarette & Gr from $05.07-08.07$, damaged by ice & & \\
\hline 3 & Ste-Catherine $(250 \mathrm{t})$ & 71.04 Ciboure & 71.09 .10 & M. de Conigant & Gr from 05.20 to 08.15 & & \\
\hline 4 & L'Espérance $(250 \mathrm{t})$ & 71.04 Ciboure & 71.09 & D. de Haraneder & Gr from 08.06 to 08.15 & & \\
\hline 5 & L'Espérance $(350 \mathrm{t})$ & 71.05.01 Honfleur & 71.09 via Ostende & I. Le Cordier & Gr 05.26-07.29; Is 08.17-09.03 & & \\
\hline 6 & $\begin{array}{l}\text { Notre Dame des } \\
\text { Carmes }(250 \mathrm{t})\end{array}$ & 74.04:12 Ciboure & $\begin{array}{l}\text { 74.10.05 Le Havre } \\
\text { 74.10.06 Honfleur }\end{array}$ & P. Descheres & Left Gr 08:26 & & \\
\hline 7 & $\begin{array}{l}\text { Marie de St-Vincent } \\
(250 \mathrm{t})\end{array}$ & 75.05.21 Ciboure & 75.09 .02 & $\begin{array}{l}\text { P. Daccarette } \\
\text { le jeune }\end{array}$ & Gr 06.25 -end August & & \\
\hline 8 & $\begin{array}{l}\text { Ville de Bruxelles } \\
(250 \mathrm{t})\end{array}$ & 75.04.30 Ciboure & 75.10 .12 & D. de Haraneder & $\begin{array}{l}\text { Gr } 0.6 .12-08.26 \text {. Frozen in } 46 \text { days. } \\
\text { Took Dutch ship Is. }\end{array}$ & 6 & 220 \\
\hline 9 & St.-François $(180 \mathrm{t})$ & 76.04.03 Ciboure & 76.09 .22 & L. Deccarette & $\begin{array}{l}\text { Gr. } 05: 12-08.20 \text { Is. Collision, broke } \\
\text { bowsprit. Surgeon died. }\end{array}$ & & \\
\hline 10 & $\begin{array}{l}\text { Ville de Bruxelles } \\
(250 \mathrm{t})\end{array}$ & 76.04.04 Ciboure & 76.08 .22 & J. de Gasteluzard & $\begin{array}{l}\text { Gr. } 04.28-07.08 \text {; damaged by ice } \\
\text { Gr 05.28. }\end{array}$ & & \\
\hline 11 & St-François $(300 \mathrm{t})$ & 77.04 .22 St-J de L & 77.10 .06 & M. de Larreguy & Gr 05.27; left ice in Sept. & 8 & 330 \\
\hline 12 & St-François $(180 \mathrm{t})$ & 77.04.18 St-J de L & 77.09 .07 & $\begin{array}{l}\text { J. Peritz de } \\
\text { Hirigoyen }\end{array}$ & Gr 05.28; left ice 07.20 & 14 & 500 \\
\hline 13 & $\begin{array}{l}\text { Marie de St-Vincent } \\
(250 \mathrm{t})\end{array}$ & 77.04.23 Ciboure & 77.10 .04 & P. Daccarette & Gr 05.28 ; headed $81^{\circ} \mathrm{N}$; left ice 08.23 & 19 & 620 \\
\hline 14 & $\begin{array}{l}\text { Notre Dame de } \\
\text { Bonne-Nouvelle } \\
(200 \mathrm{t})\end{array}$ & $\begin{array}{l}\text { Conge } 77.04 .21 \\
\text { St-J de L }\end{array}$ & 77.09 .15 & B. Duhart & Gr end May-08.26 & 16 & 450 \\
\hline 15 & St-François $(180 \mathrm{t})$ & 78.04.02 Ciboure & 78.09 .02 & P. de Bereau & Gr end June-07.18 & & 440 \\
\hline 16 & $\begin{array}{l}\text { Notre Dame de } \\
\text { Bonne-Nouvelle } \\
(200 \mathrm{t})\end{array}$ & 78.04.12 St-J de L & 78.09 .03 & B. Duhart & Gr 06.05 ; left ice 07.22 & 18. & 580 \\
\hline 17 & St-François (180.t) & 79.04.01 Ciboure & 79.09 .21 & P. de Bereau & Gr 06.06 & & 440 \\
\hline 18 & $\begin{array}{l}\text { Notre Dame des } \\
\text { Carmes }(250 \mathrm{t})\end{array}$ & 79.04.12 Ciboure & 79.09 .07 & J. de Larralde & Gr 05.27-07.05. Seaman drowned. & & 750 \\
\hline 19 & Marie $(100 \cdot t)$ & 80.05:12 Bayonne & 80.09 & M. Lance & Gr 06.25-08.06: Lost 24 lines. & 6. & 260 \\
\hline 20 & St-François $(150 \mathrm{t})$ & 80.0408 Ciboure & 80.10 .09 & P. de Bereau & $\begin{array}{l}\text { Gr } 06.24-08.12 ; \text { Is. } 09.07-09-17 \text {. } \\
\text { Rudder broken.by ice. }\end{array}$ & 17 & 470 \\
\hline 21 & Marie $(200 \mathrm{t})$ & 80.04.03 St-J de L & 80.08 .21 & J. de Gasteluzard & Left Gr 07.02; Is. . & & \\
\hline 22 & $\begin{array}{l}\text { Notre Dame des } \\
\text { Carmes }(150 \mathrm{t})\end{array}$ & $\begin{array}{l}\text { 81.03.30 Passajes } \\
\text { (Spain) }\end{array}$ & 81.09 .04 & J. de Larralde. & Gr 04.28-08.01; man drowned. & 29 & 700 \\
\hline 23 & St-Etienne $(160 \mathrm{t})$ & 81.03.10 Honfleur & 81.09 .05 & M. Martin & $\begin{array}{l}\text { To Passajes } 03.18-04.15 \\
\text { Gr } 06.07-07.06 ; \text { is } 07.21-08.07 ; \text { man } \\
\text { killed by whale. }\end{array}$ & 22 & 670 \\
\hline 24 & Marie $(100 \mathrm{t})$ & 82.03.08 Honfleur & 82.10 .05 & N. Piquet. & $\begin{array}{l}\text { Complete fitting-out St-J de L; Is. } \\
\text { Repaired leak in Is. }\end{array}$ & 8 & 273 \\
\hline 25 & St-Etienne $(160 \mathrm{t})$ & 82.04.12 Honfleur & 82.09 .13 & M. Martin & Gr 06.30-07.17; Is. & 17 & 570 \\
\hline 26 . & Vierge $(100 \mathrm{t})$ & $83.03 \mathrm{St}-\mathrm{J}$ de L & 83.09 .22 & J. de Larralde & Gr 05.19-07.13; Is. & 13 & 425 \\
\hline 27 & St-Etienne $(160 \mathrm{t})$ & 83.04.13 Honfleur. & 83.10 .03 & M. Martin & $\mathrm{Gr}$; fast in ice. & $8^{1 / 2}$ & 206 \\
\hline 28 & Vierge $(100 \mathrm{t})$ & $\begin{array}{l}\text { Sea-brief } 84.04 .18 \\
\text { Honfleur }\end{array}$ & $+?$ & M. de Larralde & No return report: & & \\
\hline 29 & St-Etienne $(160 \mathrm{t})$ & 84.04 .23 Honfleur & 84.09 .23 & M. Martin & Gr 05.19-08.01; Is. & 11 & 360 \\
\hline 30 & St-Etienne $(160 \mathrm{t})$ & 85.04.17 Honfleur & 85.10 .01 & M. Martin & Gr 05.22; fast in ice, 07.02-08.11; Is. & 12 & 280 \\
\hline 31 & St-Etienne $(160 \mathrm{t})$ & 87.04.16 Honfleur & 87.10 .08 & M. Martin & Gr 05.29; Is. Sick man died. & 9 & 236 \\
\hline 32 & St-Etienne $(160 \mathrm{t})$ & 88.04.17 Honfleur & 88.09 .26 & M. Martin & $\begin{array}{l}\text { Fast in ice. } 80^{\circ} \mathrm{N} \text {. Sick man died. } \\
\text { Only catch a narwhal. }\end{array}$ & $\mathbf{0}$ & \\
\hline
\end{tabular}


TABLE 2. Ownership* and crew of certain whaling campaigns. Numbers refer to Table 1

\begin{tabular}{lllll}
\hline \hline $\begin{array}{lll}\text { Campaign } \\
\text { No. }\end{array}$ & Year & $\begin{array}{l}\text { No. of } \\
\text { Cannon }\end{array}$ & Crew & Shipowners \\
\hline 2 & 1669 & 8 & & Pierre Daccarette \\
3 & 1671 & 12 & 48 & Dusault \\
5 & 1671 & 6 & 52 & A. Lecordier and others \\
6 & 1674 & $14-15$ & 55 & Fabien de Bruix (1/4) \\
7 & 1675 & 12 & 50 & Widow of Joannis Daccarette (13/14) \\
8 & 1675 & 14 & 50 & \\
9 & 1676 & $8-10$ & 35 & Delalande (1/8), N. Mesnager (1/24) \\
10 & 1676 & 12 & 48 & Jacques Alleaume (1/8) \\
11 & 1677 & 14 & & Delalande $(4 / 16)$ \\
12 & 1677 & $8-10$ & 40 & Delalande (1/8) \\
13 & 1677 & 14 & & \\
14 & 1677 & 10 & 40 & \\
15 & 1678 & $8-10$ & & Jean Casebielle, Delalande (1/8) \\
16 & 1678 & 10 & & Joachim de Turbide (1/2) \\
17 & 1679 & $8-10$ & & Delalande \\
25 & 1682 & 6 & 43 & \\
27 & 1684 & 14 & 39 & \\
28 & 1684 & 6 & 30 & \\
30 & 1685 & 6 & 40 & \\
31 & 1687 & 12 & & Pallier (1/2) \\
32 & 1688 & 6 & 41 & Claude Giffard \\
\hline
\end{tabular}

*Principal source: Polices d'Assurances de la Chambre des Assurances de Paris, Archives Nationales Z1D 75-80; for 31 and 32: Z1D 81; for 25, 27, 28 , 30, and 32: rôles d'équipage, Amirauté de Honfleur, 2(II):273.

1676. This probably explains why this ship came into Honfleur in 1669, 1676, 1677, 1678, 1679, and 1680.

The case of the Marie de St-Vincent is a little different, for the Basque owner had an agent at Honfleur. In 1675, 13/14 of the ship belonged to the widow of Joannis Daccarette; she arrived at Honfleur "loaded with oil and whalebone for the account of Mr. Charles Thierry, of this said town ..."'6. The ship returned again to Honfleur in 1676 but was so badly damaged that it could not be repaired.

Very often the insurance policies of the whalers which left the Pays Basque stated that they could return to Le Havre de Grâce, to Honfleur, or even to other ports. Several whalers made port at Honfleur when they should have gone to Le Havre. The Sainte-Ursule in 1668, the Notre Dame des Carmes in 1674, and the Marie in 1680 all put into Honfleur instead of Le Havre for unexpected reasons. The Soleil, which had left Cherbourg in May 1683, should have returned to Le Havre or Honfleur, and since its name is not in the Honfleur reports, it must have gone to Le Havre. ${ }^{7}$ All the available indications tend to show that a large number of whalers returned to Le Havre, a view which is reinforced by a rapid glance through the admiralty papers in Le Havre, though there is unfortunately no complete run of reports. ${ }^{8}$ We know of a total of 57 whalers which returned to port at Le Havre from 16681689.

On seeing the profits made by the Basques on unloading their cargoes at Honfleur, the merchants of this port soon considered the advantages of furnishing their own ships. In 1671 Abraham Lecordier and some other Honfleur merchants equipped the Esperance (350 tons), whose captain was Isaac Lecordier. This ship was wrecked abeam off Ostende on the return journey and it was not until 1681 that another whaler took to the water from Honfleur. This was the 160-ton SaintEtienne under the command of Michel Martin, which made seven trips from Honfleur, leaving each year from 1681 to 1688 with the exception of 1686 . In 1681 she went to the Spanish port of Passage to complete her fitting-out, where she also took on a pilot, some harpooners, and other expert whalers. In 1687 half the ship belonged to Monsieur Pallier; in 1688 it was listed as the property of Claude Giffard.9

In 1682 another ship, the Marie, set sail from Honfleur but she went to complete her equipment at Saint-Jean de Luz and the name of the owner is not known.

In 1684 the Vierge, which had returned the previous year from Saint-Jean de Luz to Honfleur, weighed anchor from the Norman port. The lack of any further report indicates that this ship was probably lost.

The ships which had left the Pays Basque and put in at Honfleur left again under ballast for their home ports, for example the Marie in 1675, the Ville de Bruxelles in 1675 and 1676, and the Saint-François in $1676 . .^{10}$

\section{The Crews}

For 14 out of the 32 whaling campaigns we know the number of sailors in the crew (see Table 2). The smallest number was that of the Vierge (100 tons), which in 1684 had a crew of only 30 men and carried only four whaleboats. The other ships carried at least five whaleboats and had crews of between 39 and 55 men. The muster-rolls for the Saint-Etienne are preserved for $1682,1684,1685$, and 1688 , and for the Vierge for $1684 . " 1$

In 1684 the master of the Saint-Etienne was Michel Martin, aged 46, who was probably not Basque. The crew consisted of 19 Basques from Bayonne or Saint-Jean de Luz, and 19 Normans. All the skilled whaling jobs were held by Basques: the pilot, five harpooners, the first mate, two carpenters, three coopers, two coxswains, one chief valet, two with no precise job, and a 17-year-old boy. The Normans included the ship's doctor, two carpenters, one gunner and one cooper, the others being ordinary seamen from Honfleur, Le Havre de Grâce, or Cherbourg.

In the case of the Vierge (see muster-roll in appendix A), 24 of 30 men were Basques, including the master, Michel de La Ralde. Only six men were Norman: the gunner and the ordinary seamen.

Apart from Michel Martin, only two of the other 32 whaler captains were not Basque, one being Isaac Lecordier, the commander of the Esperance in 1671. According to his report, the Basque members of the crew abandoned ship during the shipwreck without making any effort to help him try to save her. The other non-Basque captain was Nicolas Piquet of the Marie, which went to complete her fitting-out at Saint-Jean de Luz in 1682. All the other captains were Basques, and some of their careers can be followed over a period of many years.

The documents consulted so far give no indication as to the payment of the crews but we know that the Basques were paid with the lay-system, which means with a share of the catch. 
The 24 Normans taken on as ordinary seamen on the Soleil from Cherbourg in 1683 were paid a fixed monthly wage which varied from $\mathfrak{1} 10$ to $\mathfrak{2 2 2}$. They were advanced two months' wages from which interest was deducted on their return, at the rate of $30 \%$ (38\% in the event of war).

Life on board was extremely hard, mainly because of the cold when whaling in the ice; and it is somewhat surprising that there were so few deaths aboard the whalers. Every death is mentioned in the reports. There were six in all during the 31 fishing campaigns - three from sickness, two from drowning, and one man was killed by a whale.

When a ship foundered in the ice, which did not happen to any of the ships in this study, the crew was rescued by other whalers in the vicinity. In 1680 the Saint-François took on board 10 men from the Basque whaler Saint Michel, "wrecked in the ice", who had first been retrieved by a Dutch whaler. In 1685 the Saint-Etienne et Saint Charles just escaped being broken up in the ice. The crew had put the boats and survival rations on the ice in case their ship was completely wrecked, "having seen the ship lifted in the air several times by the ice". However, the ice relaxed its grip and the ship was freed on 23 August.

In 1681 Saint-Etienne saw several Dutch whalers wrecked and took aboard five men from the Lion Noir from Rotterdam.

\section{THE CONDUCT OF THE WHALING EXPEDITIONS}

\section{Dates of Departure and Return (see Table 1)}

A spring start was necessary in order that the whalers could arrive in the Arctic as the pack ice was breaking up, to facilitate fishing in the ice. The ships left the Pays Basque between the end of March and the beginning of May: In theory the whalers from Honfleur could have left later, but in practice they usually left towards the middle of April. The SaintEtienne and the Marie, both of which competed their fittingout in the Pays Basque, sailed on 10 March 1681 and 8 March 1682 , respectively.

The whalers returned as soon as they had completed their cargoes, which for the Marie was 21 August in 1680, for the Ville de Bruxelles 22 August in 1676, and for the Sainte Ursule 30 August 1668.

If the catch was insufficient, however, the ships stayed as late as possible in the ice, but it made good sense to leave this area by the second half of July or the beginning of August. Fishing was still possible in Icelandic waters, so the return was sometimes delayed until September or the beginning of October. The latest recorded return was that of the SaintFrançois on 9 October 1680.

\section{The Whaling Grounds}

Information on the whereabouts of the whaling grounds is fairly imprecise, but generally speaking they were around Greenland or Spitsbergen during the seventeenth century. Whaling was no longer carried out in the bays but out at sea (pelagic whaling) where the whales were cut up alongside the ship. The whaling vessels felt their way along channels in the floating ice, a process which often invited damage. For example, the Saint-François was "battered by the ice"' in 1669, the Ville de Bruxelles was damaged in 1676, and the rudder of the Saint François was broken by ice in 1680 . It is stated in a report that the Marie de Saint Vincent reached $81^{\circ} \mathrm{N}$ in 1677 and the Saint-Etienne $80^{\circ} \mathrm{N}$ in 1688 , which suggests they were fishing betwen Spitsbergen and Greenland. The whalers were often held fast in the pack ice for varying periods. The Ville de Bruxelles was frozen in for 46 days, escaping only on 26 August 1675. The Saint-Etienne was trapped in 1683, 1685, and 1688 - which explains her mediocre catches in these years.

If the cargo was not compete by the end of the season in the ice, it was still possible to fish for the smaller "Sardes" in Icelandic waters until September.

Of the 31 fishing campaigns mentioned in this study, 21 were carried out in Greenland and in the ice. In addition, nine ships fished around Iceland on the way back. The Marie, which had completed her preparation at Saint-Jean de Luz in 1682 , had to repair a leak in Iceland. She then continued fishing "near to the place called Sarde, because it was too late to go to the Grande Baie". Did they call this region of Iceland "la Sarde" after the name of the species of whale that they hunted there? It is not at all certain that this is the case, for the captain who wrote the report was not a Basque and could well have been muddled over this point. The "Grande Baie" was the name the Basques gave the Gulf of Saint Lawrence, where they had found a new species of whale, bigger than the "Sardes" they had hunted up until then, which they labelled "the Great Bay whale", "baleine de Grande Baie". This was the name of the species that they hunted in the ice, so "aller à la Grande Baie" at that time did not mean to go to the Gulf of St. Lawrence, but to fish for the Great Bay whale in the northern ice.

The 1675 report of the Ville de Bruxelles also uses a curious geographical expression: the ship "left the ice to come to Sarde, to a country called Philleur or Ilan" - by which. it almost certainly meant Iceland. ${ }^{12}$

\section{The Method of Whaling}

The whaleboats were crewed by six men - the harpooner, four oarsmen, and the coxswain in charge of the boat. They had to get sufficiently close to throw the harpoon so that it hooked its barbs into the whale's flesh. Normally the whale sounded and the fishermen let the line run. As soon as the whale surfaced to breathe the line was hauled in until the whale was close enough to be speared with leaf-shaped lance whose points came out easily. It sometimes took several hours to kill a whale and many escaped, either because the harpoon became unhooked, the line broke, or the men had to cut the line if the whale plunged under the ice.

The reports give little detail about fishing but do describe two accidents. In 1680 the Marie "lost 24 lines which she had used for whaling". That must mean that many lines had been broken or cut, and in some cases that they had to be let go if the whale fled further than the length of rope; or perhaps that 
some whaleboats had overturned or broken up with the loss of equipment on board.

On board the Saint-Etienne on 29 July 1681 "the said Biastrie of Siboure was knocked out of the whaleboat by a whale, carried off and drowned without us being able to help"'.

\section{The Produce from Whaling}

We have no information on the quantity of whalebone brought back. The whalebone (or baleen) which can be up to three metres long, is a hard but flexible fibrous horny strip which had many uses, e.g. as umbrella ribs or corset stays.

Whale oil was used primarily for illumination. The Dutch barrelled the blubber for trying out on their return to Holland, while the Basques boiled it down on board ship in ovens brought along for that purpose and took back the oil in casks.

It appears that the Dutch hunted only the Greenland right whale, known by the name of bowhead to the Americans and called the Grande Baie whale by the Basques. This whale was found in the ice or near the pack ice. In addition, the Basques hunted the "Sarde" whale in Icelandic waters; this was probably the smaller Biscay right whale, which gave less oil and shorter whalebone.

We know the results of 21 of the 31 whaling expeditions (Table 3), and in 17 instances the number of whales caught is stated. The campaigns from $1675-1688$ produced in total 8808 casks (barriques) of oil, an average of 440.4 for each of the 20 expeditions. The best results were those of the Notre Dame des Carmes: 750 casks in 1679 and 700 casks in 1681. The SaintEtienne was less successful, with 206 casks in 1683, 280 in 1685,236 in 1687 , and nothing at all in 1688 . The bad years were almost always those in which the ships had been blocked in the ice for long periods. The best catch was that of two ships which made port in 1681 with totals of 29 and 22 whales, respectively.

These results are quite remarkable if one considers that even in the nineteenth century it sometimes took several years to achieve the same results in distant waters.

In one report no distinction is made between whales taken off Greenland and those taken off Iceland, but in 16 other cases the number of whales caught in each area is detailed together with the corresponding number of casks of oil. Theoretically, the whales caught in the ice off Greenland were the Grande Baie whales and those near Iceland were the Sardes. On average the Greenland whale produced 31.8 casks of oil per whale and the Iceland whale 26.8 casks.

It is interesting to compare briefly the whaling of the French and the Dutch ships, for precise statistics exist for the latter. ${ }^{13}$ The Basques always prided themselves on catching more whales than their rivals, the Dutch. But one reason for this might have been that since they boiled down the blubber on board, their ships had room for the produce of more whales than the Dutch ships which returned with the blubber. ${ }^{14}$ According to our statistics, the average number of whales taken by French ships is nearly always higher than that of the Dutch in the same year (see Table 3). According to C. de Jong, the
TABLE 3. Results of 21 whaling expeditions between 1675 and 1688. Number of expedition refers to Table 1

\begin{tabular}{|c|c|c|c|c|c|c|c|c|}
\hline \multirow[b]{2}{*}{ No. } & \multirow[b]{2}{*}{ Year } & \multicolumn{2}{|c|}{ Greenland whaling } & \multicolumn{2}{|c|}{ Iceland whaling } & \multicolumn{2}{|c|}{ Total } & \multirow{2}{*}{$\begin{array}{l}\text { Average no. } \\
\text { of whales taken } \\
\text { by Dutch }\end{array}$} \\
\hline & & Whales & $\begin{array}{c}\text { Casks of } \\
\text { oil }\end{array}$ & Whales & $\begin{array}{c}\text { Casks of } \\
\text { oil }\end{array}$ & Whales & Casks & \\
\hline $\begin{array}{r}8 \\
11 \\
12 \\
13 \\
14 \\
15 \\
16 \\
17 \\
18 \\
19 \\
20 \\
22 \\
23 \\
24 \\
25 \\
26 \\
27 \\
29 \\
30 \\
31 \\
32 \\
\end{array}$ & $\begin{array}{l}1675 \\
1677 \\
1677 \\
1677 \\
1677 \\
1678 \\
1678 \\
1679 \\
1679 \\
1680 \\
1680 \\
1681 \\
1681 \\
1682 \\
1682 \\
1683 \\
1683 \\
1684 \\
1685 \\
1687 \\
1688 \\
\end{array}$ & $\begin{array}{c}6 \\
12 \\
29 \\
17 \\
14 \\
11 \\
71 / 2 \\
7 \\
11 \\
2\end{array}$ & $\begin{array}{r}220 \\
330 \\
500 \\
620 \\
450 \\
440 \\
580 \\
440 \\
750 \\
260 \\
\\
700 \\
550 \\
500 \\
375 \\
176 \\
260 \\
280 \\
76\end{array}$ & $\begin{array}{l}5 \\
8 \\
3 \\
2 \\
1 \\
4 \\
1 \\
7\end{array}$ & $\begin{array}{r}120 \\
273 \\
70 \\
50 \\
30 \\
100 \\
0 \\
160\end{array}$ & $\begin{array}{c}6 \\
17 \\
29 \\
22 \\
8 \\
17 \\
13 \\
81 / 2 \\
11 \\
12 \\
9 \\
0 \\
\end{array}$ & $\begin{array}{r}220 \\
330 \\
500 \\
620 \\
450 \\
440 \\
580 \\
440 \\
750 \\
260 \\
450 \\
700 \\
770 \\
273 \\
570 \\
425 \\
206 \\
360 \\
280 \\
236 \\
0 \\
\end{array}$ & $\begin{array}{l}5.6 \\
4.8 \\
6.5 \\
3.2 \\
1.6 \\
\end{array}$ \\
\hline Total & & & & & & 226.5 & 8808 & \\
\hline \multicolumn{2}{|l|}{ Average } & \multicolumn{2}{|c|}{$\begin{array}{l}31.8 \text { casks } \\
\text { per whale }\end{array}$} & \multicolumn{2}{|c|}{$\begin{array}{l}26.8 \text { casks } \\
\text { per whale }\end{array}$} & $\begin{array}{c}13.3 \\
\text { per } \\
\text { expedi- } \\
\text { tion }\end{array}$ & $\begin{array}{c}440.4 \\
\text { per } \\
\text { expedi- } \\
\text { tion }\end{array}$ & \\
\hline
\end{tabular}

Dutch hunted only the Grande Baie whales and not the Sardes. Even if one excludes the whales taken near Iceland, and compares only the French catch near Greenland with the annual average catch of the Dutch, one generally arrives at a higher number for the French. To confirm this theory one needs to know how to make the conversion between the casks of blubber of the Dutch and the oil casks of the French. Meanwhile one can conclude that the Basque whalers' claim to superiority over the Dutch was probably justified. Dutch strength lay in the cheaper cost of their equipment and their better commercial capacity.

\section{The War at Sea}

The war with Holland which broke out in 1672 was not unexpected, and the French whalers were strongly armed. Nevertheless, no whaling vessels put in to Honfleur in either 1672 or 1673, a year in which the number of Pays Basque ships had considerably diminished.

The Notre Dame des Carmes, which came into Honfleur in 1674 , had written into her insurance policy the right to fly the Spanish flag in case of need, which would have enabled her to escape any Dutch ships. However, no Netherlands whaler had permission to sail in 1672, 1673, and 1674, for the States General did not want to risk the ships' being taken by the enemy, and the seamen were needed for the war fleet.

The Ville de Bruxelles, which was frozen in the ice in 1675 , took a Dutch ship in the same situation, but since none of the French sailors were willing to crew their capture, they let her go after they had removed the blubber of one whale which was on board.

After the peace of Nimeguen in 1678 the spirit of mutual aid 
was renewed, and in the event of shipwreck French sailors were rescued by Dutch crews and vice versa, as had been previously done in 1680 and 1681 .

The renewal of the war in 1688 , added to the bad whaling results of the previous years, discouraged the owner of the Saint-Etienne from sending her out from Honfleur again. The number of Basque whaling ships rapidly diminished until there were only one or two left in the early eighteenth century, in contrast to the nearly 40 French whalers which had taken to sea in the 1680s. No whalers came into Honfleur again.

The 32 whaling campaigns described in this paper give an impression of what the industry was like in a time of prosperity. Unfortunately, the wars towards the end of Louis XIV's reign dealt it a fatal blow.

Only after 1714 did the whaling activities recover noticeably, and then only in the Pays Basque - and they returned only to their home ports. There were fewer experienced seamen in this region, so the Spanish Basques were called upon for their services. A new period of prosperity culminated towards 1730 with the sending out of more than 30 whalers each year. This was followed by a rapid decline, accentuated by the competition of the Dutch and Spaniards, until Basque whaling ceased completely with the outbreak of the Seven Years War. The industry never recovered in spite of several unsuccessful attempts to revitalize it.

\section{APPENDIX A \\ Muster-Roll of La Vierge in 1684 \\ Amirauté de Honfleur 2 II 273}

Roster of the Christian and surnames, ages, occupations and addresses of the officers and seamen on La Vierge under Captain M. de la Ralde on the whaling voyage to Greenland 1684.

Michel de La Ralde, from Bayonne, aged 43

Michel de La Ralde, from Bayonne, aged 38

Betry Dibarboure from St, Jean de Luz, aged 32

Joannis Dutchique, from Bayonne, aged 28

Martin Diriac, from Bayonne, aged 31

Joannis de Hirribaren, from Bayonne, aged 29

Joannis de Suldycagon, from Bayonne, aged 30

Joannis Detchegaray, from Bayonne, aged 38

Martin Detchevery, from Bayonne, aged 27

Michel de Bidard, from St. Jean de Luz, aged 32

Betrico de Bidard, from Bayonne, aged 34

Martin Dargaygarasse, from Bayonne,aged 36

Bernard de Lissague, from Bayonne, aged 25

Pitre de La Freschie, from Bayonne, aged 56

Joannis de Penoya, from Bayonne, aged 39

Joannis de Borda, from St. Jean de Luz, aged 41

Jean de Laffon, from Bayonne, aged 43

Pierre de Liquider, from Bayonne, aged 29

Joannis de Liquider, from St. Jean de Luz, aged 38

Martin de Salamon, from Bayonne, aged 45

Pierre de Thoro, from St. Jean de Luz, aged 23

Martin Duruty, from Bayonne, aged 34

Martin Daux, from Bayonne, aged 13

Captain
Pilot
First Mate
Carpenter
Carpenter
Carpenter
Cooper
Cooper
Coxswain
Coxswain
Coxswain
Harpooner
Harpooner
Surgeon
Flenser
Seaman
Seaman
Seaman
Seaman
Seaman
Seaman
Seaman
Boy

Boy
Isaac Hébert, from Havre de Grace, aged 28

Pierre Marie, from Havre, aged 31

Pierre Lengeigneur, from Honfleur, aged 12

Seaman

Seaman

Boy

\section{NOTES}

'Archives from Honfleur, Honfleur Admiralty Reports, 1665-1668, 2(II):287-296; Congés 1671-1688, 2(II): 246-255; Rôles d'équipage 1681-1688, 2(II):271-277.

${ }^{2}$ Archives Nationales, Polices d'Assurances, $\mathrm{Z}^{\mathrm{ID}}: 75-80$.

${ }^{3}$ Bibliothèque Nationale, Thoisy $148 \mathrm{f}^{\circ} 148$.

${ }^{4}$ B.N. Cinq Cents de Colbert 199, inventory of ships in French ports in 1664. (St. Jean de Luz).

sThe Saint-Etienne, called Estienne Charles, was English-built. Marine $B^{3} 55 f^{0} 300$.

${ }^{6}$ Report of 3 September 1675, 2(II):293.

${ }^{7}$ Manuscript of the Service Historique de la Marine: the signing on of the sailors for the Soleil.

${ }^{8}$ Archives of the Seine Maritime 216B, 188 articles from 1590-1789.

${ }^{9}$ Marine B3 $55 \mathrm{f} 300,20$ mars 1688 . The proprietor had great difficulty completing his crew as few Basques were available.

${ }^{10}$ Congés, 2(II):249.

"The Saint-Etienne of 160 tons had a crew of 40 and carried 5 whaleboats. The vessels of 250 tons with a crew of 50 generally carried 6 whaleboats. See Marine D2 48, mémoire du 12 février 1716.

${ }^{12}$ The fishing ground often mentioned in other documents is "Norouegue" which should not be taken in a literal sense for Norway, but more in a general sense for the whole region in the same latitude as Norway. Fisland is also mentioned, which could be a deformation of Iceland, but it should be treated with some suspicion, geographically speaking.

${ }^{13}$ Cornelis de Jong, Geschiedenis va de oude Nederlandse Walvisvaart, deel Drie (Johannesburg, 1979): 157.

${ }^{14}$ See, e.g., the Mémoire of 1751 , Marine C 10.

Officers and ordinary seamen from Normandy:

Gilles Maubrac, from Honfleur, aged 33

Charles Desmoliers from Honfleur, aged 28

Jean Tillet, from Havre de Grace, aged 25
Gunner

Seaman

Seaman 